\title{
The Quality of Social Environment and Social Accessibility of Fishing Communities in West Sumatra, Indonesia
}

By

Dr. Noviarti Zulkarnaini ${ }^{1}$

\begin{abstract}
This study explored quantitatively the quality of the social environment of the traditional fishing community and its relation to social access assistance in Padang, West Sumatera, Indonesia. The study applied three indicators: education, health, and family life. The result revealed that the overall level of social environment quality of the fishing community is high moderate (69.23), by which average score of education (68.50), health (76.86), and family life (62.34). The average social environment quality in urban areas is high moderate (71.39), while in rural areas is low moderate (66.18). T-test analysis of social quality showed that there is a significant difference to the social environment quality of life $(\mathrm{t}=$ $5.258^{* *}$ ) among fishing community in urban and rural areas. The access to social assistance does not improve the quality of social life $\left(\mathrm{t}=3.537^{* *}\right)$. Finally, the fishing community showed preference to access social assistance is consumptive rather than productive. This study suggested that in order to improve their quality of life in fishing community, the government should take into account the character of the area and the productive assistance programs.
\end{abstract}

Key words: Quality of life, fishing communities, urban poor, HDI

\section{Introduction}

The quality of social environment is closely related to the quality of human resources, hence it should receive serious attention for the development of human capital in the future. In fishing communities the quality of human resources is of primary constraint in improving their quality of life. The life of fishing communities from time to time is sufficient in terms of social status and economy. The phenomenon of poverty, low education, health and housing problems are often associated with the quality of life of fishing communities. A study on economy found that the fishing communities are one of three main groups that can be identified as the poorest groups, as well as the rural poor (farmers) and the urban poor (Elfindri 2002; Badan Pusat Statistik 2007b; 2008b). Among the identified causes of poverty is the low affordability of assets such as land, 
fishing equipment, lack of capital, the constraints of the physical environment factor, the low quality of human resources because of low level of education, health and others (Fachruddin, C 1998; Elfindri 2002; Kusnadi 2001; Ismail, Z 2000).

The fishing communities are often related with the issue of poverty. The research on poverty conducted by Badan Pusat Statistik (2007b), reported that the priority of social assistance to poor communities are direct social assistance. For the fishing communities, social assistance is required based on the direct cash transfer, food assistance, capital, health and educational assistance. This study explored the quality of social environment of the traditional fishing community and its relationship to social access assistance.

Based on Human Development Index (HDI) in 2007 for the Padang city, the overall level of HDI value is high moderate, but especially in coastal areas, the HDI value is lowest compared to other areas such as agriculture area (Badan Pusat Statistik 2007a). This indicates that the quality of socio-economic, education, and health within costal communities have lower quality than communities living in the city.

\section{Materials And Methods}

This paper explored social environment quality among fishermen households in the city of Padang, West Sumatera, Indonesia. Social quality is measured through three indicators, i.e. education, health and family life. (1) Education indicator is measured through seven sub-indicators, i.e. level of education of head of household and spouse, number of children unfinished schooling, accessibility to primary school-junior high school-senior high school and the problems related to public education services. (2) Health indicator measured through five sub indicators, i.e. main health service often used, number of family members who had endemic disease (i.e. dengue, malaria), the frequency of using public health service, accessibilty to public health service, and the problems related to public health services. The family life indicator were measured through five sub indicators, i.e. the size of household, number of children, number of dependent family members, the frequency to go for leisure, and participation in family planning.

The study was conducted on traditional fishing households in six sub-districts of the city of Padang. From this study, basic information was acquired about the fishermen household situation. Data sources included primary data via a questionnaire survey, with a sample of 271 respondents. The analysis is descriptive using frequency and mean. Moreover, in order to see the difference in the social quality among households by area and ability to access for social assistance a t test analysis was applied.

Padang is the capital and largest city of West Sumatra, Indonesia. It is located on the Western coast of Sumatra at Lat. $0^{\circ} 57^{\prime} 0^{\prime \prime} \mathrm{S}$ and Long.100 $21^{\prime} 11^{\prime \prime}$ E. It has an area of 694.96 square kilometres $(268.33 \mathrm{sq} \mathrm{mi}$ ) and a population of over 833,000 people at the 2010 Census. Padang is divided into 11 subdistricts: Bungus Teluk Kabung, Koto Tangah, Kuranji, Lubuk Begalung, Lubuk Kilangan, Nanggalo, Padang Barat, Padang Selatan, Padang Timur, Padang Utara and Pauh. 


\section{Results And Discussion}

The study reveals that the majority of $43.5 \%$ of household heads have an education level at primary school (Table 1), whilst, the household heads who do not have formal education (did not complete primary school) reached $10.7 \%$. There was only $36.9 \%$ who completed the junior high school.

More than 60.0 percent of the respondents are between 31 to 50 years old. The size of households is 5 to 6 persons $(46.7 \%)$ and more than 7 persons (15\%). In economic terms, the majority of fishermen income from fishing is 1 to 1.5 million IDR (45.8\%) and 500,000 to 1 million IDR (35.4\%).

Table 1. Socio-economic profile of respondents

\begin{tabular}{llll}
\hline No & Characteristics & Frequency & Percentage \\
\hline 1 & Level of education & & \\
& Without school/incomplete primary school & 29 & 10.7 \\
& Primary school & 118 & 43.5 \\
& Junior high School & 100 & 36.9 \\
& Senior high school & 23 & 8.5 \\
& Diploma/University & 1 & 0.4 \\
\hline 2 & Age (years) & & \\
& $<30$ & 38 & 14.2 \\
& $31-40$ & 86 & 32.2 \\
& $41-50$ & 78 & 29.2 \\
& $51-60$ & 49 & 18.4 \\
& $>60$ & 16 & 6.0 \\
\hline 3 & Size of household (person) & & \\
& $2-4$ & 102 & 37.6 \\
& $5-6$ & 127 & 46.9 \\
& $7-8$ & 31 & 11.4 \\
& $>8$ & 11 & 4.1 \\
\hline 4 & Income/ month (IDR) & & \\
& $<500,000$ & 4 & 1.5 \\
& 500,000-1,000,000 & 96 & 35.4 \\
& $1,000,100-1,500,000$ & 124 & 45.8 \\
$1,500,100-2,000,000$ & 40 & 14.8 \\
& Total $, 000,000$ & 7 & 2.6 \\
\hline & & 271 & 100.0 \\
\hline & & &
\end{tabular}

\subsection{Social Assistance Programme for Fishing Community}

The fishing community is one of the groups identified as poor households. In this context, fishing communities will access social assistance from the poverty alleviation programmes.

There were three aid package programmes that Indonesia Government has launched since 2003 in order to overcome poverty, such as : (1) Assistance and social protection 
which aims to protect and fulfil the rights to education, health, nutrition, sanitation and clean water. The package is created in the form of rice, the guarantee to health and education assistance, and direct cash transfer. (2) Community empowerment which seeks to provide protection and fulfilment of the rights to participate, to work and job opportunity, land, natural resources, environment, and housing. (3) Empowerment of micro and small businesses which aims towards protection and fulfilment of the rights to work and work opportunities, natural resources and environment (Badan Pusat Statistik 2007b; 2008a).

Based on poverty programme has provided, approximately $68-84 \%$ of the fishing households received the social assistance from the poverty programme (Table 2). Their access to food (rice subsidy) is highest (84.1\%) and access to capital is lowest (5.2\%). Their accessibility to capital assistance and equipment can support economic activities such as fish processing activities. This shows that fishing households have preference to access consumable assistance (food and direct cash transfer) rather than productive assistance (capital and equipment).

Table 2. Accessibility of fishing community on social assistance

\begin{tabular}{lllllll}
\hline $\begin{array}{l}\text { Type of assistance } \\
\text { received }\end{array}$ & Food (rice) & Health & $\begin{array}{l}\text { Direct } \\
\text { transfer }\end{array}$ & cash & Equipment & Capital \\
\hline Frequency & 228 & 185 & 186 & 66 & 14 \\
Percentage & 84.1 & 68.3 & 68.6 & 24.4 & 5.2 \\
\hline
\end{tabular}

\subsection{Social Environment Quality and Social Access}

The phenomenon of children who do not finish schooling is an educational problem that exists among the fishing households. Usually, the children drop out of school either during school or do not pursue further education after completing primary school. Table 3 shows that the number of children dropping out of school in the fishing households reached $18.8 \%$, according to the area compared to the children with unfinished schooling in rural area which is higher than in urban city, reaching $21.4 \%$.

Table 3. Distribution of children who do not finish schooling among fishing households

\begin{tabular}{llll}
\hline Variable & All respondents & Urban & Rural \\
\hline Finish schooling & 18.8 & 17.0 & 21.4 \\
Do not finish schooling & 81.2 & 83.0 & 78.6 \\
Total & 100.0 & 100.0 & 100.0 \\
\hline
\end{tabular}

Furthermore, the three indicators of social quality, namely: education, health and family life as shown in Table 4, reveal that the overall level of quality of education and health among fishing households are on average higher, while for the quality of the family is at the low moderate. This shows that the quality aspect of the family is still very low. 
Table 4. Mean score by social indicators among fishing community

\begin{tabular}{llll}
\hline Indicator & Urban & Rural & All responden \\
\hline Education & 71.96 & 63.58 & 68.50 \\
Health & 78.27 & 74.87 & 76.86 \\
Family life & 63.93 & 60.08 & 62.34 \\
\hline Social Quality & 71.39 & 66.18 & 69.23 \\
\hline
\end{tabular}

Note: level of score: $\quad<50 \%=$ low; $50 \%-65 \%=$ low moderatel;

$66 \%-80 \%=$ high moderatel; $>80 \%=$ high

In addition, the social quality according to the three indicators mentioned earlier found that the overall mean score of social quality of fishing community are on average high at 69.23. However, when compared to the social quality of urban and rural areas, a mean score of social quality in the city are at their highest average with a mean score of 71.39, while in rural areas at a low average level of 66.18 . This is proven by the statistical t-test analysis (Table 5) which shows that there is a significant difference the social environment quality among fishing community in urban and rural areas $(\mathrm{t}$ value $=5258$ and $\mathrm{p}<0.01)$.

Table 5. Mean and t-test of social environment quality

\begin{tabular}{lcccc}
\hline Variable & $\mathrm{N}$ & Mean & St. deviation & T value \\
\hline By area & & & & \\
Urban & 159 & 71.39 & 6.08 & $5.258^{* *}$ \\
Rural & 112 & 66.18 & 7.56 & \\
By social accesbility & & & & $3.537^{* *}$ \\
Have access & 159 & 68.04 & 8.71 & \\
No access & 112 & 71.86 & 7.11 &
\end{tabular}

Social accessibility studied in this research refers to accessibility to social assistance. Social assistance refers to poverty social assistance programmes. Further studies also looked at the influence of social support on social quality of fishing community. There are differences between the social environment quality of households receiving social poverty assistance with those who do not receive any. It was found that the score mean quality of respondents who do not receive social poverty assistance is higher than those who are receiving it. Based on t-test analysis, it shows that there are significant differences between the social quality of respondents who do not receive social assistance with those who receive social assistance with the value $t=3537$. This finding shows that the social assistance programme is probably a direct impact on poor households in order to reduce spending on food. However its influence on the social improvement of poor households are not directly effective. It means the social poverty assistance has not been directly effective for poor households.

Social quality is measured through the three components: education; health; and quality of family life. The rational relationship between these indicators leads to improved education which will influence positively on the health aspect of the family's quality of 
life. It will improve the overall quality of life of the fishermen. This study proves that differences exist in the social quality of fishing communities who live in urban and rural areas. Two problems are obvious in the social quality of the fishing community. These are education and quality of family life. The education problems are low education level of household heads and high number of children who do not finish schooling. Additionally, the access to education of rural communities is lower than urban communities. The sources of these problems are the distance of school from the house and the quality of school services. Besides, a trend of unfinishing high school was also noticed. Moreover, the quality of family problems are associated with large number of family members and low participation of the family in the family planning. This proved nearly $70 \%$ of respondents who have a total of 5 household members or more. It relates to the Statistics Bureau's findings in 2008 that the average number of poor households is 4.6 or equal to 5 people or more.

Quality of family correlated closely with other indicators such as education, health and economy conditions. The high rates of those who do not finish schooling among the fishing community was explained by Yulia, A (2009). There was a 55\% who did not finish schooling because they lack motivation and attention of parents for their children's education to continue their school. This is not due to family economic pressure, but easy to get a second income from fishing activities, (2) $50.0 \%$ is due to households perception that education is less important for children and only $3.45 \%$ allocation of total income per month for child's education, and (3) $41.7 \%$ due to environment factor.

When related with social development, the social quality in rural area shows that social development is very slow. But, social capital is a form of education other than the investment of human capital development which could provide a major role in improving the quality of people, whilst, the human education is a major role in improving the quality of life.

The unfinished schooling is relatively high in rural areas and the tendency of children to work is relatively large due to more opportunities to get the money from fishing activity. Complexity of the social quality issue resulted in inequality in quality of life of urban communities compared to that of rural communities. If the government does not handle the situation immediately, then vulnerability appears in community life. The government should reevaluate and make a few adjustments to policy development paradigm that focus on the rural area and why their development is running low. Improvement of transportation infrastructure, education and health are among the first steps to be taken into account in improving equal distribution of development between regions. These are the main problems as to why the rural areas are very difficult to develop. This situation should be considered in order to lead our community and increase social capital and givepositive impact on the development of other areas and future development.

Inequality of the development of a region or country can be associated with some aspects of the geographical, economic, demographic, cultural and political sectors. Inequality of development means not only in economic terms, but also influence the social life such as health and education (Coates et al. 1977). Then it will indirectly impact on the quality of life. The existence of inequalities of development over the years has always been a problem for development (World Bank 2003; Mubyarto 2005). This phenomenon shows the regional difference in spatial conditions such as differences in 
the rate of progress or backwardness compared with other regions. Differences can be seen in terms of regional economic growth, the economic of communities, health, education and accessibility (Ahmad, A 2008; Coates et al. 1977). Fishing communities are identified as poor communities. Then, they are the target group for recipients of social assistance. However, based on results of this study, the social assistance has not been a significant influence on their social quality improvement. Even those who accept it, their social quality is still low compared to those who do not receive any social assistance. Many studies found that poverty assistance is only temporary, and does not yet show significant improvement on the quality of social life. In other words, social assistance is mainly consummary and not for production. It is different with the quality of life of fishing communities in Terengganu, Malaysia. Muda, M.S et al. (2006) found that the role of government was a significant influence on the quality of life of fishermen in Terengganu, Malaysia. The role of government is intended mainly to improve economic productivity of fishermen i.e. infrastructure support, training courses, advisory services, marketing, regulatory, research and development of fishing.

\section{Conclusion}

The social quality of a society does not directly reflect the quality of human resources who will have an impact on the development of human capital in the future. In fishing communities the quality of social problems still exist especially in education and the quality of family life. This social problem is reflective of the quality of the fishing communities who live in rural areas. Although the government has launched a social assistance to provide for poor communities, this direct assistance does not influence the social improvement of fishing community. In the future the government could focus on improving the social quality of rural fishing communities, especially in education and the quality of the family. In addition, the government should promote the fishing community to access the social assistance in improving their quality of life.

\section{References}

Ahmad, A., (2008), Manifestasi pembangunan tak seimbang di Malaysia melalui ketaksamaan kesejahteraan sosial. In. Katiman Rostam, Mokhtar Jaafar \& Noorazuan Md Hashim (Eds.). Dinamika Sosial, Pembangunan dan Persekitaran di Malaysia. Bangi: Penerbit Universiti Kebangsaan Malaysia. pp.1-26.

Badan Pusat Statistik, (2007a), Indeks Pembangunan Manusia Kota Padang. Padang: Badan Pusat Statistik.

Badan Pusat Statistik, (2007b), Analisis Tipologi Kemiskinan Perkotaan 2007. Jakarta: Badan Pusat Statistik.

Badan Pusat Statistik, (2008), Analisis dan Penghitungan Tingkat Kemiskinan 2008. Jakarta: Badan Pusat Statistik.

Fachruddin, C., (1998), Labuhan Deli: Organisasi Sosial Sebuah Komuniti Melayu di Sumatera Utara, Indonesia. Ph.D Tesis, Fakulti Sains Sosial dan Kemanusiaan. Universiti Kebangsaan Malaysia, Bangi. (Unpublished).

Coates, B.E., Johnston and Knox, (1977), Geography and Inequality. Oxford: Oxford University Press.

Elfindri, (2002), Ekonomi Patron-Client: Fenomena Mikro Rumah Tangga Nelayan dan Kebijakan Makro. Padang: Andalas University Press.

Kusnadi, (2001), Pangamba: Kaum Perempuan Fenomenal Pelopor dan Penggerak Perekonomian Masyarakat Nelayan. Bandung: Humaniora Utama Press.

Muda, M.S., W.M. Amin, W.M. Aziz and Omar, N.W., (2006), Analisis kesejahteraan hidup nelayan pesisir. Jurnal Kemanusiaan, 8: 58-77. 
Mubyarto, (2005), A development manifesto: The Resilience of Indonesia Ekonomi Rakyat During the Monetary Crisis. Jakarta: Penerbit Kompas.

World Bank, (2003), The urbans within transition: urban sector overview of decentralisation in Indonesia. Urban Development Working Papers No. 7.

Yulia, A., (2009), Strategi Penuntasan Wajib Belajar Sembilan Tahun pada Level Rumah Tangga di Kabupaten Pasaman: Implikasi Terhadap Pencapaian MDGs. Padang: Lembaga Penelitian Universitas Andalas.

Ismail, Z., (2000), Pemberdayaan ekonomi masyarakat wilayah pesisir Indonesia: Telaah ekonomi nelayan dan petani tambak. In. Indonesia Menapak. Abad ke-21: Kajian Ekonomi Politik. Jakarta: Lembaga Ilmu Pengetahuan Indonesia (LIPI). pp 196-230. 